\title{
Synthesis, Characterization and Antibacterial Activity of New Complexes of Some Lanthanide Ions with Benzo 18-Crown-6 and 221-Cryptand
}

\author{
Basim I. Alabdaly ${ }^{1}$, Mohammed H. A. Al-Almery ${ }^{1}$, and Mustafa K. Albayaty ${ }^{1}$

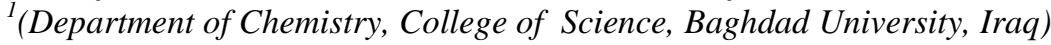

\begin{abstract}
Complexes of some lanthanide picrates $\left(\mathrm{Ln}^{3+}=\mathrm{Pr}^{3+}, \mathrm{Nd}^{3+}\right.$ and $\left.\mathrm{Dy}^{3+}\right)$ with benzo-18-crown-6 and 221-cryptand were synthesized and characterized by elemental analysis, FTIR, and UV-Visible. Spectrophotometric methods, thermal analysis (TGA \& DTG), melting point, magnetic susceptibility and molar conductance. Also an in-vitro study on gram positive (Staphylococcus aureus) and gram negative bacteria (Escherichia coli, Salmonella and pseudomonas aeruginosa) was performed and the results were compared to those of the broad spectrum antibiotic Chloramphinicol. The benzo-18-crown-6 complexes have the general formula of [Ln.L.(Pic $\left.)_{2}\right]$ Pic.nH $\mathrm{H}_{2} \mathrm{O}$, where; $\left(\mathrm{Ln}^{3+}=\mathrm{Pr}^{3+}, \mathrm{Nd}^{3+}\right.$, and $\left.\mathrm{Dy}^{3+}\right),(L=$ Benzo-18-crown-6),$($ Pic $=$ Picrate anion), $(n=1-2)$. In these complexes two picrate anions are coordinated to the metal ion through the phenolic oxygen and oxygen of the ortho nitro group, thus, the metal ions in these complexes have a coordination number of (10). The complexes of 221-cryptand have the general formula of [Ln.L.(Pic)]Pic $2_{2} \cdot n \mathrm{H}_{2} \mathrm{O}$ where; $\left(\mathrm{Ln}^{3+}=\mathrm{Pr}^{3+}, \mathrm{Nd}^{3+}\right.$, and $\left.\mathrm{Dy}^{3+}\right),(\mathrm{L}=221$-cryptand $),($ Pic $=$ Picrate anion $),(n=$ 1,2 or 7). In these complexes one picrate anion is coordinated to the metal ion, also through the phenolic oxygen and the oxygen from the ortho nitro group, thus the metal ions in the cryptand complexes have a coordination number of (9).
\end{abstract}

Keywords: crown ethers, lanthanides, picrates, cryptand

\section{Introduction}

The coordination chemistry of lanthanides is important. And during the last decades, an increase in the number of publications devoted to the rare earth coordination compounds has been observed[1-6], due to their biological, biochemical, medical and many other applications such as an excellent diagnostic and prognostic probe in clinical diagnostics[7], an anticancer material [2,8], lanthanide complexes based X-ray contrast imaging and lanthanide chelates based contrast enhancing agents for Magnetic Resonance Imaging (MRI)[9] are being excessively used in radiological analysis in our body systems [8], also as shift reagents for NMR spectrometry [9-11], as well as, their potential applications in fundamental and applied science such as organic synthesis, bioorganic chemistry and homogeneous catalysis[9,12-16]. Crown ethers are cyclic chemical compounds that consist of a ring containing several ether groups. The most common crown ethers are oligomers of ethylene oxide, the repeating unit is ethyleneoxy, i.e., $-\mathrm{CH}_{2} \mathrm{CH}_{2} \mathrm{O}-$-[17]. Since its discovery by Pedersen [18], many variants of those structures have been reported, such as out-in bicyclic amines and cryptands by Simmons and Park, Lehn and coworkers, lariat ethers, aza-crown ethers, calixarenes and calixcrowns, calixtubes[19]. All these compounds are interesting because of their remarkable selectivity on metal cations, especially from alkali and alkaline earth metals [20-24], which is a topic of fundamental interest in both coordination and biological chemistry [25]. Complexation reactions of crown ethers and cryptands with $4 f$-element salts under anhydrous conditions promote interaction of the metal ion with the crown ether in solution; however these complexes are often very difficult to crystallize [3,4] but we have successfully prepared, characterized and tested the crystallized complexes against gram positive (Staphylococcus aureus) and gram negative bacteria (Escherichia coli, Salmonella and pseudomonas aeruginosa) in-vitro. They showed good, promising results when compared to the well-known broad spectrum antibiotic Chloramphenicol, in fact chloramphenicol had no activity at all against the gram negative pseudomonas aeruginosa while all the tested complexes showed good inhibitions. However further in-vivo study is required. The biological activity of these complexes against these bacteria is believed to arise from the crown ligand (The Chelate) effect on the metal ion. The most important property of the chelating agents, in lanthanide chelate complex, is its ability to alter the behavior of lanthanide ion with which it binds in biological systems, and the chelation markedly modifies the bio distribution and excretion profile of the lanthanide ions. The chelating agents increase the proportion of their complex excreted from complexes lanthanide ion from biological systems [2]. 


\section{Materials And Methods}

All the Starting materials were commercially available. The ligands (benzo 18-crown-6 and 221cryptand) were obtained from Sigma Aldrich Company, lanthanide oxides, picric acid and the solvents were obtained from Merck Company and were used without further purification. The lanthanide content was determined by EDTA titration using xylenol orange as an indicator. The carbon, hydrogen and nitrogen content were determined using the Carlo Erba EA 1108 elemental analyzer. The IR spectra were recorded using $\mathrm{KBr}$ pellets and an $8400 \mathrm{~S}-$ FTIR SHIMADZU spectrometer. The UV - Visible Spectra were recorded using an 1800 - UV SHIMADZU spectrometer. Conductivity measurements were carried out using a HI 9811 - 5 Portable HANNA $\mathrm{pH} / \mathrm{EC} / \mathrm{TDS} /{ }^{\circ} \mathrm{C}$ meters. Thermal analysis of the prepared complexes was performed using SHIMADZU 60-H Thermo Gravimetric Analyzer. The melting points were measured using a GALLENKAMP melting point apparatus. The magnetic properties were measured using a Johnson Matthey MSB MarkI magnetic susceptibility balance.

\section{Preparation of lanthanide picrate:}

General procedure: $(1 \mathrm{mmole})$ of lanthanide oxide was placed in a round bottomed flask, followed by the addition of $(40 \mathrm{ml})$ of $(0.05 \mathrm{M})$ picric acid and refluxed at $\left(85^{\circ} \mathrm{C}\right)$ until all the oxide was dissolved, the process took few hours to more than 24 hours. The clear yellow solution was filtered while still hot then the filtrate was concentrated on a heater at $\left(40-50{ }^{\circ} \mathrm{C}\right)$ to half of its volume after that the solution was left over night to be air concentrated (if you want to accelerate the process then evaporate the solution on the heater very slowly and on a low temperature, care must be taken since the metal salts of picric acid are highly explosive more than the acid itself but the slower the rate of the concentration the better yield you get). After the concentration and the evaporation of the solution yellow-dark yellow crystals were formed, all the crystals were collected and stored in a desiccator. The colors of the salts were bright yellow-orange. The general equation for the preparation of lanthanide picrates is shown below:

$\mathrm{Ln}_{2} \mathrm{O}_{3(\mathrm{~s})}+6\left(\mathrm{NO}_{2}\right)_{3} \mathrm{C}_{6} \mathrm{H}_{2} \mathrm{OH}_{(\mathrm{aq} .)} \longrightarrow{ }^{2} \mathrm{LnPic}_{3} \cdot \mathrm{xH}_{2} \mathrm{O}$

Where $\mathrm{Ln}^{3+}=\mathrm{Pr}^{3+}, \mathrm{Nd}^{3+}$ and $\mathrm{Dy}^{3+}$

\section{Preparation of B18-crown-6 complexes:}

General procedure: a solution of (1 mmole) of B18-crown- 6 in $(3 \mathrm{ml})$ of absolute ethanol was added to a solution of $(0.5 \mathrm{mmole})$ of lanthanide picrate in $(3 \mathrm{ml})$ of absolute ethanol and refluxed at $\left(60{ }^{\circ} \mathrm{C}\right)$ for one hour, then the solution was left overnight. The developed precipitate or crystals were collected and stored in a desicator for 24 hours. In some cases a gummy like precipitate formed. The gummy precipitate was treated with $\left(40-60{ }^{\circ} \mathrm{C}\right)$ petroleum ether for several times till a fine powder precipitate was formed. The obtained crystals were yellow-orange.

\section{Preparation of 221-cryptand complexes:}

General procedure: a solution of (2 mmole) of 221-cryptand in $(10 \mathrm{ml})$ of absolute ethanol was added to a solution of $(1 \mathrm{mmole})$ of lanthanide picrate in $(10 \mathrm{ml})$ of absolute ethanol at room temperature. Immediate precipitation occured along the addition, then the precipitate was filtered and washed with small proportions of ethanol; finally the precipitate was placed in a desiccator and left for 24 hours for complete dryness. The colors of the complexes were yellow-dark orange.

\section{Physical and Chemical measurements:}

\section{Results}

The carbon, hydrogen, nitrogen and metal content data alongside the melting points, colors, conductivity values, and magnetic moments of the prepared complexes are shown in table (1).

\section{IR spectra:}

IR spectra of the lanthanide picrates: The data of the absorption frequencies of picric acid and lanthanide picrates are listed in table (2). The most important band shift is the one that belongs to the $v(\mathrm{O}-\mathrm{H})$ stretching vibration which is shifted in the spectra of the salts by $\left(367-397 \mathrm{~cm}^{-1}\right)$ towards higher wave numbers when compared to the spectra of picric acid, this may be due to the breaking of the intramolecular hydrogen bonding between the phenolic hydrogen and the oxygen from the adjacent nitro group, and the formation of an ion pair between the $\mathrm{Ln}^{3+}$ ion and $\mathrm{Pic}^{-}[26,36]$. Some noticeable shifts in the bands of the symmetric and asymmetric stretching vibrations of the nitro groups are observed in the spectra of the lanthanide salts when compared to the 
spectra of picric acid as it is shown in table (3), this also may indicate the breaking of the intramolecular hydrogen bonding between the oxygen of the nitro group and the phenolic hydrogen [36-39, 41].

IR spectra of the complexes: The data of the absorption frequencies for the free ligands and their complexes are shown in table (3). The most important band in the spectra of the complexes is that of the (C-O-C) stretching vibration. Compared with the free ligand the $v(\mathrm{C}-\mathrm{O}-\mathrm{C})$ bands in the complexes of B18-crown- 6 are shifted by $\left(99 \mathrm{~cm}^{-1}\right)$ for the first band and by $\left(35 \mathrm{~cm}^{-1}\right)$ for the second band towards lower wave numbers with changes in shape and intensity of the peaks, while the bands in the complexes of 221-crypantd are shifted by $\left(29-35 \mathrm{~cm}^{-1}\right)$ also towards lower wave numbers and are also accompanied with changes in shapes and intensities of the peaks. These shifts and spectral changes give an indication of the interaction between the crown compound and the metal ion and the magnitude of the shift defines the strength of the interaction which varies from one ligand to another due to the size matching between the cavity of the ligand and the size of the metal ion alongside other factors [27-31]. Some new bands appear in the spectra of the complexes which are absent in the spectra of the free ligand at around $\left(1537-1560\right.$ and $\left.1325-1337 \mathrm{~cm}^{-1}\right)$ these bands belong to the asymmetric and symmetric stretching vibrations of the nitro groups of the picrate anion, this confirms the formation of the complexes and means that the picrate anions are incorporated in the skeleton of the complexes whether coordinated to the metal ion or as a counter ion. Any shift in these bands when compared to the bands of their corresponding metal salts indicates their coordination to the metal ion [37-39, 41]. Significant shifts are observed in the complexes when compared to the spectra of the corresponding lanthanide salt as shown in table (3) indicating that some picrate anions are coordinated to the metal ion which is confirmed by their conductance values. Another new band appeared at $\left(3092-3097 \mathrm{~cm}^{-1}\right)$ in the spectra of 221-cryptand complexes which is absent in the spectra of the ligand and is assigned to the aromatic $v(\mathrm{C}-\mathrm{H})$ stretching vibration of the aromatic ring of the picrate anion, and another band appeared at $\left(932-943 \mathrm{~cm}^{-1}\right)$ which belongs to the aromatic $\delta(\mathrm{C}-\mathrm{H})$ bending vibration, the appearance of these two bands mean that the picrate anions are somehow incorporated in the complex. The $\mathrm{CH}_{2}$ bending vibrations (Scissoring, wagging and rocking) experienced shifts in their bands when compared to the free ligand, some shifts are high and obvious, some are simple and all these shifts are accompanied with changes in shapes and intensities of the peaks. These spectral changes are may be due to the decrease in charge density on the adjacent oxygen atom, which gives an indication of their bonding and interaction with the metal ion [30]. Another new band appeared at $\left(1610-1614 \mathrm{~cm}^{-1}\right)$ in the spectra of 221-cryptand complexes, this band is assigned to the $v(\mathrm{C}=\mathrm{C})$ stretching vibration of the benzene ring of the picrate anions, this is absent in the spectra of the free ligand $[38,39,41]$.

\section{UV - Visible Spectra:}

The electronic spectra of picric acid and lanthanide salts were recorded in ethanol. Picric acid shows two main absorption bands at $(\lambda$ max 359 and $220 \mathrm{~nm}$ ). These bands are shifted to lower wave lengths in the corresponding salts. These spectral changes may indicate the formation of ion-pair between $\mathrm{Ln}^{3+}$ ion and $\mathrm{Pic}^{-}$in $\mathrm{LnPic}_{3}$ which is also confirmed by IR results. The electronic spectra of free ligands and their complexes were recorded in DMSO. Table (4) shows the absorption data of picric acid, Ln salts, ligands and the complexes. All ligands show two typical absorption bands as it is seen in table (4), one of these two bands is shifted to a higher wave length specifically to $(380 \mathrm{~nm})$ in all the complexes while the other band is shifted to a lower wavelength table (4). These spectral changes confirms that the complex is formed indicating that there is a change in the environment and leads to the conclusion that $\mathrm{Ln}^{3+}$ is maybe incorporated in the ligand causing these spectral changes. The picrate anion also have a pronounced effect on the formation of the complex and the nature of the spectra and since the maximum absorption bands of the lanthanide picrate salts are shifted upon complexation to other wave lengths that means the picrate anions one, or more are coordinated to the metal ions[32,33, 40].

\section{Thermal analysis:}

The $\mathrm{Pr}^{3+}, \mathrm{Nd}^{3+}$, and $\mathrm{Dy}^{3+}$ complexes of B18-crown-6 showed almost similar thermal behavior and results. All the three complexes went through three stages in their thermal decomposition; the first stage was the dehydration step, followed by the second stage which was the decomposition of the anhydrous complex into unidentified intermediates due to the explosive nature of the picrate compounds, and finally the third stage, the formation of Ln oxides $[26,34,35]$. The dehydration process took place at a temperature range of $\left(66-120^{\circ} \mathrm{C}\right)$. The complex $\left[\operatorname{Pr}(\mathrm{B} 18 \text {-crown-6)(Pic) })_{2}\right] \mathrm{Pic} .2 \mathrm{H}_{2} \mathrm{O}$ lost one water molecule when heated to $\left(73.8^{\circ} \mathrm{C}\right)$ and lost another water molecule when heated to $\left(120.52{ }^{\circ} \mathrm{C}\right)$, it is really hard to distinguish the coordinated water from the uncoordinated water from the graphical data[30,31], the values of the weight loss found in the process $(1.4 \%$ and $2.03 \%)$ are in good agreement with the calculated values (1.5\% and $2.3 \%$ respectively). Both $\mathrm{Nd}^{3+}$ and $\mathrm{Dy}^{3+}$ complexes lost one water molecule when heated to $\left(66.35\right.$ and $\left.76.51{ }^{\circ} \mathrm{C}\right)$ respectively, the weight losses found in the process $(1.58 \%$ and $1.98 \%$ respectively) were in good agreement with the calculated values $(1.55 \%$ and $2.2 \%$ respectively). All the three complexes started to decompose at a temperature range of $\left(260-315{ }^{\circ} \mathrm{C}\right)$, 
an endothermic peak followed by an adjacent exothermic peak appeared at this range of temperature and multiple explosions took place at the same temperature range due to the explosive nature of picrate compounds forming unidentified intermediates [26]. After this temperature range other weight losses were recorded up to $\left(600{ }^{\circ} \mathrm{C}\right)$, at this temperature $\mathrm{Ln}$ oxides were formed $[26,27]$ which were stable against heating up to more than $\left(800{ }^{\circ} \mathrm{C}\right)$. The complexes of cryptand showed similar behavior, and the data are shown in table (5).

\section{Molar conductance:}

The molar conductance values of all the complexes were measured in DMSO at $25{ }^{\circ} \mathrm{C}$. The values obtained lie in the range $\left(50-80 \mathrm{Ohm}^{-1} \cdot \mathrm{cm}^{2} \cdot \mathrm{mol}^{-1}\right)$, this indicates that all the complexes are electrolytes and shows that in benzo-18-crown-6 complexes two picrate anions are coordinated to the metal ion leaving one picrate anion uncoordinated as a counter ion, while in 221-cryptand complexes only one picrate anion is coordinated to the metal ions [42].

\section{Antibacterial assay:}

All the prepared complexes were tested in-vitro against four types of pathogenic bacteria, one gram positive (Staphylococcus aureus) and three gram negative (Escherichia coli, Salmonella and pseudomonas aeruginosa), and their results were compared to the results of the broad-spectrum antibiotic chloramphenicol. They showed good promising results when compared to the commercial antibiotic, they showed clear inhibition zones some larger than those of the antibiotic, some similar and others smaller. The notice worthy case was that the antibiotic chloramphenicol showed no activity at all against the pathogenic bacteria pseudomonas aeruginosa while all the prepared complexes showed very good results, another case was that the prepared complexes showed greater activity against Staphylococcus aureus than the antibiotic. The inhibition zones measured in millimeters are listed in table (6). Further in-vivo studies are required in order to estimate the side effects of these complexes and to study their behavior inside the biological system.

\section{Discussion}

All benzo-18-crown-6 complexes have the suggested formula [Ln.L.(Pic) $\left.)_{2}\right] \mathrm{Pic}^{-} \mathrm{nH}_{2} \mathrm{O}$, while all 221cryptand complexes have the general suggested formula [Ln.L.(Pic)]Pic $2 \cdot \mathrm{nH}_{2} \mathrm{O}$ where; $\left(\mathrm{Ln}^{3+}=\mathrm{Pr}^{3+}, \mathrm{Nd}^{3+}\right.$, $\left.\mathrm{Dy}^{3+}\right),(\mathrm{L}=\mathrm{B} 18$-crown-6 or 221-cryptand), (Pic = picrate anion), $(\mathrm{n}=1,2$ or 7$)$, which is confirmed by their elemental and thermal analysis. The molar conductance values of the complexes lie in a range which confirms that there are two picrate anions coordinated to the $\mathrm{Ln}^{3+}$ ion in benzo-18-crown- 6 complexes, and one picrate anion coordinated to the metal ions in 221-cryptand complexes which is also confirmed by their IR spectra through the shift in both symmetric and asymmetric $\left(\mathrm{NO}_{2}\right)$ stretching vibrations, and also confirmed by their UV - Visible Spectra. The spectral changes and the shifts in the (C-O-C) stretching vibration indicates that the $\mathrm{Ln}^{3+}$ ion lies inside the cavity of B18-crown-6 and is encapsulated by 221 -cryptand, these shifts also indicate the strong interaction between the $\mathrm{Ln}^{3+}$ ions and the ligands, this is due to the size matching between the radius of the ion and the size of the cavity of the ligand, $\left(1.34-1.43 \mathrm{~A}^{\circ}\right)$ for B 18 -crown- 6 and $\left(1.013,0.995,0.912 \mathrm{~A}^{\circ}\right)$ for $\mathrm{Pr}^{3+}, \mathrm{Nd}^{3+}$ and $\mathrm{Dy}^{3+}$ respectively. Two picrate anions are coordinated to the metal ion through their phenolic oxygen and the oxygen of the nitro group, to give rise to the coordination number of (10) in B18-crown-6 complexes, and one picrate anion is coordinated to the metal ions in 221-cryptand to give rise to the coordination number (9). These coordination numbers are not uncommon since lanthanides offer the possibility of a wide range of coordination numbers (up to 12), although coordination numbers (8) and (9) are the favorable but other coordination numbers exist too. The UV - Visible Spectra of the prepared complexes confirmed their formation through the simple shifts and changes of intensities of their peaks since it is known that the $f$ orbitals are deeply buried inside the atom and are well shielded from the environment so upon complexation with ligands, only minimal changes are observed in the electronic absorption and emission spectra, such as small displacements in the peak positions, and changes in the relative intensities of some of the emission peaks. All the prepared complexes are of explosive nature at a temperature higher than $\left(260^{\circ} \mathrm{C}\right)$ as it is indicated by their thermal analysis which is the nature of all picrate compounds and a common behavior in most nitro compounds. All the prepared complexes were tested in-vitro against four types of pathogenic bacteria, one gram positive (Staphylococcus aureus) and three gram negative (E. Coli, Salmonella, and Pseudomonas aeruginosa), and the results were compared to that of the broad spectrum antibiotic Chloramphenicol. The results were very good in comparison to the antibiotic and they were the best against pseudomonas aeruginosa. Pseudomonas aeruginosa is resistant to most of the well-known antibiotics, and chloramphenicol showed no activity at all against Pseudomonas aeruginosa while all the prepared complexes showed very good results, their inhibition zones measured in millimeters are listed in table (6). One of the expected mechanisms for the action of these complexes on the tested bacteria is believed to be related to the metal-chelation or the effect of the chelate (the ligand) on the metal ion. The most important property of the chelating agents (ligands), in lanthanide chelate 
complex, is its ability to alter the behavior of lanthanide ion with which it binds in biological systems, and the chelation markedly modifies the bio distribution and excretion profile of the lanthanide ions.

\section{Acknowledgements}

We are grateful for all those who helped and supported us during our work in the department. And I present my special thanks and gratitude to my supervisors Dr. Basim I. Al-Abdaly and Dr. Mohammed H. A. Al-Almery for their guidance, efforts, knowledge and support.

Table (1): Elemental analysis, colors, melting points, magnetic moments and the conductivity values of the Metal salts and their corresponding complexes

\begin{tabular}{|c|c|c|c|c|c|c|c|c|}
\hline $\begin{array}{c}\text { Formula } \\
\text { M.wt.(gm/mole) }\end{array}$ & $\begin{array}{c}\mathrm{C} \% \\
\text { Cal. } \\
\text { (found) }\end{array}$ & $\begin{array}{c}\mathrm{H} \% \\
\text { Cal. } \\
\text { (found) }\end{array}$ & $\begin{array}{c}\mathrm{N} \% \\
\text { Cal. } \\
\text { (found) }\end{array}$ & $\begin{array}{c}\text { M\% } \\
\text { Cal. } \\
\text { (found) }\end{array}$ & Color & M.P. ${ }^{\circ} \mathrm{C}$ & $\begin{array}{c}\text { Magneti } \\
\mathrm{c} \\
\text { moment } \\
\text { BM } \\
\end{array}$ & $\left.\Omega^{1} \mathrm{~cm}^{2} \cdot \mathrm{mol}^{-1}\right)$ \\
\hline $\begin{array}{c}\operatorname{Pr}(\mathrm{Pic})_{3} .6 \mathrm{H}_{2} \mathrm{O} \\
933.2866\end{array}$ & $\begin{array}{l}23.165 \\
(23.055 \\
)\end{array}$ & $\begin{array}{c}1.944 \\
(1.823)\end{array}$ & $\begin{array}{l}13.507 \\
(13.452)\end{array}$ & $\begin{array}{l}15.098 \\
(14.897)\end{array}$ & yellow & $98-100$ & 4.4 & $\ldots .$. \\
\hline $\begin{array}{c}\mathrm{Nd}(\mathrm{Pic})_{3} .6 \mathrm{H}_{2} \mathrm{O} \\
936.6189\end{array}$ & $\begin{array}{l}23.082 \\
(22.938 \\
)\end{array}$ & $\begin{array}{c}1.937 \\
(1.902)\end{array}$ & $\begin{array}{c}13.459 \\
(13.323)\end{array}$ & $\begin{array}{c}15.400 \\
(15.304)\end{array}$ & $\begin{array}{l}\text { Deep } \\
\text { yellow }\end{array}$ & $59-62$ & 5.9 & $\ldots .$. \\
\hline $\begin{array}{c}\text { Dy(Pic) })_{3} .3 \mathrm{H}_{2} \mathrm{O} \\
900.8333\end{array}$ & $\begin{array}{c}23.999 \\
(23.713 \\
)\end{array}$ & $\begin{array}{c}1.343 \\
(1.137)\end{array}$ & $\begin{array}{l}13.994 \\
(13.802)\end{array}$ & $\begin{array}{c}18.039 \\
(17.754)\end{array}$ & $\begin{array}{l}\text { Bright } \\
\text { yellow }\end{array}$ & $65-68$ & 11.1 & $\ldots .$. \\
\hline $\begin{array}{c}\left.\mathrm{Pr}(\mathrm{B} 18 \mathrm{C} 6)(\mathrm{Pic})_{2}\right] \mathrm{Pic} .2 \mathrm{H}_{2} \\
\mathrm{O} \\
1173.583 \\
\end{array}$ & $\begin{array}{c}34.796 \\
(34.250 \\
\quad) \\
\end{array}$ & $\begin{array}{l}2.920 \\
(2.830)\end{array}$ & $\begin{array}{c}10.741 \\
(10.410)\end{array}$ & $\begin{array}{c}12.007 \\
(11.850)\end{array}$ & yellow & $60-62$ & 5.4 & 50 \\
\hline $\begin{array}{c}\left.\mathrm{Nd}(\mathrm{B} 18 \mathrm{C} 6)(\mathrm{Pic})_{2}\right] \mathrm{Pic} . \mathrm{H}_{2} \\
\mathrm{O} \\
1158.9001\end{array}$ & $\begin{array}{l}35.237 \\
(35.052 \\
)\end{array}$ & $\begin{array}{l}2.783 \\
(2.620)\end{array}$ & $\begin{array}{c}10.878 \\
(10.680)\end{array}$ & $\begin{array}{l}12.446 \\
(12.146)\end{array}$ & orange & $75-80$ & 8.9 & 50 \\
\hline $\begin{array}{c}\left.\text { Dy(B18C6)(Pic })_{2}\right] \text { Pic. } H_{2} \\
\text { O } \\
1177.1601 \\
\end{array}$ & $\begin{array}{c}34.650 \\
(34.450 \\
\quad \\
\end{array}$ & $\begin{array}{l}2.740 \\
(2.630)\end{array}$ & $\begin{array}{l}10.709 \\
(10.520)\end{array}$ & $\begin{array}{c}13.804 \\
(13.680)\end{array}$ & $\begin{array}{l}\text { Dark } \\
\text { yellow }\end{array}$ & $80-84$ & 11.2 & 50 \\
\hline $\begin{array}{c}{\left[\mathrm{Pr}(221)\left(\mathrm{Pic}^{2}\right)\right] \mathrm{Pic}_{2} \cdot \mathrm{H}_{2} \mathrm{O}} \\
1175.645\end{array}$ & $\begin{array}{c}34.735 \\
(34.087 \\
)\end{array}$ & $\begin{array}{c}3.429 \\
(3.850)\end{array}$ & $\begin{array}{l}13.105 \\
(12.614)\end{array}$ & $\begin{array}{l}11.986 \\
(11.542)\end{array}$ & $\begin{array}{c}\text { Dark } \\
\text { orange }\end{array}$ & $110-112$ & 5.8 & 80 \\
\hline $\begin{array}{c}{[\mathrm{Nd}(221)(\mathrm{Pic})] \mathrm{Pic}_{2} .7 \mathrm{H}_{2} \mathrm{O}} \\
1287.0685\end{array}$ & $\begin{array}{c}31.728 \\
(31.541 \\
) \\
\end{array}$ & $\begin{array}{c}4.072 \\
(3.821)\end{array}$ & $\begin{array}{c}11.971 \\
(11.432)\end{array}$ & $\begin{array}{l}11.207 \\
(11.013)\end{array}$ & orange & $110-114$ & 7.1 & 60 \\
\hline $\begin{array}{c}{[\mathrm{Dy}(221)(\mathrm{Pic})] \mathrm{Pic}_{2} .2 \mathrm{H}_{2} \mathrm{O}} \\
1215.2525\end{array}$ & $\begin{array}{c}33.603 \\
(33.090 \\
)\end{array}$ & $\begin{array}{c}3.483 \\
(3.247)\end{array}$ & $\begin{array}{c}12.678 \\
(12.349)\end{array}$ & $\begin{array}{c}13.372 \\
(13.127)\end{array}$ & orange & $104-108$ & 11.6 & 70 \\
\hline
\end{tabular}

Table (2): The absorption frequencies of picric acid and lanthanide picrates

\begin{tabular}{|c|c|c|c|c|}
\hline Compound & $v(\mathrm{O}-\mathrm{H}) \mathrm{cm}^{-1}$ & $v(\mathrm{~N}-\mathrm{O}) \mathrm{cm}^{-1}$ & $\delta(\mathrm{C}-\mathrm{H}) \mathrm{cm}^{-1}$ & $v(\mathrm{C}-\mathrm{O}) \mathrm{cm}^{-1}$ \\
\hline Picric acid & 3105 & 1527 & 941 & 1088 \\
& & 1342 & 919 & 1085 \\
\hline $\mathrm{Pr}(\mathrm{Pic})_{3} \cdot 6 \mathrm{H}_{2} \mathrm{O}$ & 3502 & 1541 & 921 & 1083 \\
& & 1360 & 908 & 1087 \\
\hline $\mathrm{Nd}(\mathrm{Pic})_{3} \cdot 6 \mathrm{H}_{2} \mathrm{O}$ & 3472 & 1541 & 943 & 926 \\
\hline Dy(Pic $)_{3} \cdot 3 \mathrm{H}_{2} \mathrm{O}$ & 3495 & 1362 & 919 & \\
& & 1340 & & \\
\hline
\end{tabular}

Table (3): The absorption frequencies of ligands and complexes

\begin{tabular}{|c|c|c|c|c|c|c|c|c|c|}
\hline Compound & $\begin{array}{l}v \quad(\mathrm{C}- \\
\mathrm{H}) \\
\text { aromat } \\
\text { ic } \\
\mathrm{cm}^{-1}\end{array}$ & $\begin{array}{l}\mathrm{v}(\mathrm{C}-\mathrm{H}) \\
\mathrm{CH}_{2} \\
\text { group } \\
\mathrm{cm}^{-1}\end{array}$ & $\begin{array}{l}v(\mathrm{~N}-\mathrm{O}) \\
\mathrm{cm}^{-1}\end{array}$ & $\begin{array}{l}\delta \mathrm{Sci} . \\
\mathrm{CH}_{2} \\
\text { group } \\
\mathrm{cm}^{-1}\end{array}$ & $\begin{array}{l}\delta \\
\text { wag. } \\
\mathrm{CH}_{2} \\
\text { group } \\
\mathrm{cm}^{-1}\end{array}$ & $\begin{array}{l}\text { Sroc } \\
\mathrm{CH}_{2} \\
\text { group } \\
\mathrm{cm}^{-1}\end{array}$ & $\begin{array}{l}\text { v (C-O- } \\
\mathrm{C}) \\
\mathrm{cm}^{-1}\end{array}$ & $\begin{array}{l}\delta(\mathrm{C}-\mathrm{H}) \\
\text { aromati } \\
\mathrm{c} \mathrm{cm}^{-1}\end{array}$ & $\begin{array}{l}\text { v } \\
(\mathrm{C}=\mathrm{C}) \\
\text { Stretch } \\
\mathrm{cm}^{-1}\end{array}$ \\
\hline B18-crown-6 & 3053 & 2929 & $\ldots \ldots$ & 1454 & $\begin{array}{l}1355 \\
1255\end{array}$ & 850 & $\begin{array}{l}1221 \\
1117\end{array}$ & $\ldots \ldots$ & 1627 \\
\hline $\begin{array}{c}{[\mathrm{PrB} 18 \mathrm{C} 6} \\
\left.(\mathrm{Pic})_{2}\right] \text { Pic } 2 \mathrm{H}_{2} \mathrm{O}\end{array}$ & 3098 & 2877 & $\begin{array}{l}1543 \\
1327 \\
\end{array}$ & 1495 & $\begin{array}{l}1362 \\
1273 \\
\end{array}$ & 847 & $\begin{array}{l}1122 \\
1082 \\
\end{array}$ & $\begin{array}{l}922 \\
953 \\
\end{array}$ & 1634 \\
\hline $\begin{array}{c}{[\mathrm{NdB} 18 \mathrm{C} 6} \\
\left.(\mathrm{Pic})_{2}\right] \mathrm{Pic} . \mathrm{H}_{2} \mathrm{O}\end{array}$ & 3102 & 2874 & $\begin{array}{l}1539 \\
1327 \\
\end{array}$ & 1425 & $\begin{array}{l}1364 \\
1273 \\
\end{array}$ & 847 & $\begin{array}{l}1122 \\
1082 \\
\end{array}$ & 926 & 1612 \\
\hline $\begin{array}{c}{[\mathrm{DyB} 18 \mathrm{C} 6} \\
\left.(\mathrm{Pic})_{2}\right] \mathrm{Pic} . \mathrm{H}_{2} \mathrm{O}\end{array}$ & 3110 & 2872 & $\begin{array}{l}1537 \\
1325 \\
\end{array}$ & 1425 & $\begin{array}{l}1364 \\
1277 \\
\end{array}$ & 849 & $\begin{array}{l}1124 \\
1082 \\
\end{array}$ & $\begin{array}{l}926 \\
947 \\
\end{array}$ & 1630 \\
\hline 221-cryptand & $\ldots \ldots$ & 2873 & $\cdots \cdots$ & $\begin{array}{l}1471 \\
1446\end{array}$ & $\begin{array}{l}1355 \\
1292\end{array}$ & 829 & $\begin{array}{l}1099 \\
1029\end{array}$ & $\ldots \ldots$ & ..... \\
\hline
\end{tabular}


Synthesis, Characterization and Antibacterial Activity of New Complexes of Some Lanthanide

\begin{tabular}{|c|c|c|c|c|c|c|c|c|c|}
\hline$[\mathrm{Pr}(221)$ & 3097 & 2916 & 1551 & 1491 & 1364 & 845 & 1070 & 943 & 1612 \\
$\left(\mathrm{Pic}_{2}\right) \mathrm{Pic}_{2} . \mathrm{H}_{2} \mathrm{O}$ & & & 1333 & 1435 & 1265 & & 1038 & & 1637 \\
\hline$[\mathrm{Nd}(221)$ & 3094 & 2901 & 1560 & 1489 & 1364 & 849 & 1064 & 932 & 1610 \\
$\left.\left(\mathrm{Pic}_{\mathrm{N}}\right)\right] \mathrm{Pic}_{2} .7 \mathrm{H}_{2} \mathrm{O}$ & & & 1335 & 1441 & 1267 & & 1036 & & 1637 \\
\hline $\begin{array}{c}\text { [Dy.(221).(Pic)]Pic } 2.2 \\
\mathrm{H}_{2} \mathrm{O}\end{array}$ & 3092 & 2878 & 1556 & 1491 & 1366 & 845 & 1078 & 943 & 1636 \\
\hline
\end{tabular}

Table (4): The absorption data of picric acid, lanthanide picrates, ligands and complexes

\begin{tabular}{|c|c|c|}
\hline Compound & $\lambda(\mathrm{nm})$ & A \\
\hline \multirow{2}{*}{ Picric acid } & 359 & 1.421 \\
\hline & 220 & 1.480 \\
\hline \multirow[t]{2}{*}{$\operatorname{Pr}(\mathrm{Pic})_{3}$} & 357 & 1.260 \\
\hline & 213 & 1.385 \\
\hline \multirow[t]{2}{*}{$\mathrm{Nd}(\mathrm{Pic})_{3}$} & 344 & 1.127 \\
\hline & 203 & 2.825 \\
\hline \multirow[t]{2}{*}{ Dy(Pic $)_{3}$} & 357 & 1.622 \\
\hline & 204 & 3.476 \\
\hline \multirow[t]{2}{*}{ B18-crown-6 } & 337 & 0.018 \\
\hline & 278 & 2.893 \\
\hline \multirow[t]{2}{*}[\mathrm{PrB}18\mathrm{C}6(\mathrm{Pic})_{2}]{$\mathrm{Pic} .2 \mathrm{H}_{2} \mathrm{O}$} & 380 & 0.833 \\
\hline & 254 & 1.077 \\
\hline $\left.\multirow[t]{2}{*}{\mathrm{NdB} 18 \mathrm{C} 6 \text { (Pic) }}_{2}\right] \mathrm{Pic} . \mathrm{H}_{2} \mathrm{O}$ & 380 & 0.785 \\
\hline & 255 & 1.050 \\
\hline \multirow[t]{2}{*}[\mathrm{DyB}18\mathrm{C}6(\mathrm{Pic})_{2}]{$\mathrm{Pic} . \mathrm{H}_{2} \mathrm{O}$} & 380 & 0.662 \\
\hline & 253 & 0.820 \\
\hline \multirow[t]{2}{*}{ 221-cryptand } & 340 & 0.198 \\
\hline & 280 & 1.782 \\
\hline \multirow[t]{2}{*}[\mathrm{Pr}(221)(\mathrm{Pic}^{2})]{$\mathrm{Pic}_{2} \cdot \mathrm{H}_{2} \mathrm{O}$} & 380 & 0.956 \\
\hline & 267 & 0.232 \\
\hline \multirow[t]{2}{*}[\mathrm{Nd}(221)(\mathrm{Pic}^{2})]{$\mathrm{Pic}_{2} .7 \mathrm{H}_{2} \mathrm{O}$} & 380 & 0.976 \\
\hline & 259 & 0.636 \\
\hline \multirow[t]{2}{*}[\mathrm{Dy}(221)(\mathrm{Pic}^{2})]{$\mathrm{Pic}_{2} \cdot 2 \mathrm{H}_{2} \mathrm{O}$} & 379 & 1.069 \\
\hline & 258 & 0.547 \\
\hline
\end{tabular}

Table (5): The data of thermal analysis of the prepared complexes

\begin{tabular}{|c|c|c|c|c|c|c|}
\hline \multirow{2}{*}{ Compound } & \multirow{2}{*}{ Step } & \multirow{2}{*}{$\begin{array}{l}\text { Temp. range } \\
\text { of the } \\
\text { decomposition } \\
\left({ }^{\circ} \mathrm{C}\right)\end{array}$} & \multirow{2}{*}{$\begin{array}{l}\text { Suggested formula of } \\
\text { the resultant } \\
\text { compound }\end{array}$} & \multicolumn{2}{|c|}{$\begin{array}{c}\Delta \mathrm{m}(\%) \\
\text { mass-loss }\end{array}$} & \multirow{2}{*}{$\begin{array}{l}\text { Temp. range of } \\
\text { thermal stability of } \\
\text { the complex }\left({ }^{0} \mathrm{C}\right)\end{array}$} \\
\hline & & & & Cal. & Obs. & \\
\hline \multirow[t]{2}{*}[\mathrm{PrB}18\mathrm{C}6(\mathrm{Pic})_{2}]{$\mathrm{Pic} .2 \mathrm{H}_{2} \mathrm{O}$} & 1 & $73-120$ & {$\left[\mathrm{Pr} . \mathrm{B} 18 \mathrm{C} 6(\mathrm{Pic})_{2}\right] \mathrm{Pic}$} & 3.10 & 3.47 & \multirow[t]{2}{*}{$120-245$} \\
\hline & 2 & $245-300$ & $*$ & $\ldots$ & $\ldots$ & \\
\hline \multirow{2}{*}[\mathrm{NdB}18\mathrm{C}6(\mathrm{Pic})_{2}]{$\mathrm{Pic} . \mathrm{H}_{2} \mathrm{O}$} & 1 & $49-66$ & [Nd.B18C6.(Pic) $\left.)_{2}\right] \mathrm{Pic}$ & 1.55 & 1.58 & \multirow{2}{*}{$66-210$} \\
\hline & 2 & $210-310$ & $*$ & $\ldots$ & $\ldots$ & \\
\hline \multirow[b]{2}{*}[\mathrm{DyB}18\mathrm{C}6(\mathrm{Pic})_{2}]{$\mathrm{Pic} . \mathrm{H}_{2} \mathrm{O}$} & 1 & $45-76$ & [Dy.B18C6.(Pic $\left.)_{2}\right]$ Pic & 2.20 & 1.98 & \multirow[b]{2}{*}{$76-223$} \\
\hline & 2 & $223-317$ & $*$ & $\ldots$ & $\ldots$ & \\
\hline \multirow[b]{2}{*}[\mathrm{Pr}(221)(\mathrm{Pic})]{$\mathrm{Pic}_{2} \cdot \mathrm{H}_{2} \mathrm{O}$} & 1 & $52-120$ & [Pr.(221).(Pic)]Pic ${ }_{2}$ & 2.28 & 2.22 & \multirow[b]{2}{*}{$120-220$} \\
\hline & 2 & $220-287$ & $*$ & $\ldots$ & $\ldots$ & \\
\hline \multirow[b]{2}{*}[\mathrm{Nd}(221)(\mathrm{Pic})]{$\mathrm{Pic}_{2} .7 \mathrm{H}_{2} \mathrm{O}$} & 1 & $47-205$ & [Nd.(221).(Pic)]Pic ${ }_{2}$ & 9.78 & 10.67 & \multirow[t]{2}{*}{$205-263$} \\
\hline & 2 & $263-322$ & $*$ & $\ldots$ & $\ldots$ & \\
\hline \multirow{3}{*}{$\mathrm{Dy}(221)\left(\mathrm{Pic}^{2}\right] \mathrm{Pic}_{2} \cdot 2 \mathrm{H}_{2} \mathrm{O}$} & 1 & $101-175$ & [Dy.(221).(Pic)]Pic 2. & 4.38 & 4.71 & \multirow{3}{*}{$175-198$} \\
\hline & 2 & $198-236$ & $*$ & $\ldots$ & 15.42 & \\
\hline & 3 & $236-325$ & $*$ & $\ldots$ & $\ldots$ & \\
\hline
\end{tabular}

(*): explosive material (unidentified)

Table (6): Inhibition zones of the ligands, prepared complexes and the broad spectrum antibiotic measured in millimeters (concentration of the samples $10 \mathrm{mg} / \mathrm{ml}=10000 \mu \mathrm{g} / \mathrm{ml}$ )

\begin{tabular}{|c|c|c|c|c|}
\hline Compound & $\begin{array}{c}\text { Inhibition } \\
\text { zone }(\mathrm{mm}) \\
\text { Escherichia coli }\end{array}$ & $\begin{array}{c}\text { Inhibition } \\
\text { zone }(\mathrm{mm}) \\
\text { Staphylococcus } \\
\text { aeureus }\end{array}$ & $\begin{array}{c}\text { Inhibition } \\
\text { zone }(\mathrm{mm}) \\
\text { Salmonella }\end{array}$ & $\begin{array}{c}\text { Inhibition zone(mm) } \\
\text { Pseudomonas aeruginosa }\end{array}$ \\
\hline DMSO & - & - & - & - \\
\hline Chloramphinicol & 22.5 & 13.0 & 25.5 & - \\
\hline B18-crown-6 & - & - & - & - \\
\hline 221-cryptand & - & - & - & 20.0 \\
\hline PrB18C6 $\left.(\mathrm{Pic})_{2}\right]$ Pic. $2 \mathrm{H}_{2} \mathrm{O}$ & 19.0 & 23.0 & 20.5 & - \\
\hline
\end{tabular}


Synthesis, Characterization and Antibacterial Activity of New Complexes of Some Lanthanide

\begin{tabular}{|c|c|c|c|c|}
\hline$\left[\mathrm{NdB} 18 \mathrm{C} 6(\mathrm{Pic})_{2}\right] \mathrm{Pic} . \mathrm{H}_{2} \mathrm{O}$ & 16.5 & 17.5 & 18.0 & 20.0 \\
\hline$\left[\mathrm{DyB} 18 \mathrm{C} 6(\mathrm{Pic})_{2}\right] \mathrm{Pic} . \mathrm{H}_{2} \mathrm{O}$ & 12.0 & 19.0 & 17.5 & 18.5 \\
\hline$[\mathrm{Pr}(221)(\mathrm{Pic})] \mathrm{Pic}_{2} . \mathrm{H}_{2} \mathrm{O}$ & 12.0 & 18.0 & 16.0 & 16.5 \\
\hline$[\mathrm{Nd}(221)(\mathrm{Pic})] \mathrm{Pic}_{2} .7 \mathrm{H}_{2} \mathrm{O}$ & 18.0 & 20.5 & 18.5 & 19.0 \\
\hline$[\mathrm{Dy}(221)(\mathrm{Pic})] \mathrm{Pic}_{2} \cdot 2 \mathrm{H}_{2} \mathrm{O}$ & 13.5 & 17.0 & 15.5 & 16.5 \\
\hline
\end{tabular}

\section{References}

[1] Sergey, P. B., and Anna, V. G. , Lanthanide Paramagnetic Probes for NMR Spectroscopic Studies of Fast Molecular Conformational Dynamics and Temperature Control.18-Crown-6 Intramolecular Reorientation in Complexes of Cerium(III) Chelates, Макрогетероиикль / Macroheterocycles, 5(2), 2012, pp. 178 - 181.

[2] Sudhindra, N. M., Minaz, A. G., Indira, D. M., and Ram, S. Biological and Clinical Aspects of Lanthanide Coordination Compounds, Bioiorganic Chemistry and Applications, vol. 2, 2004, pp. 3 - 4.

[3] Robin, D. R., Andrew, N. R., and Mathew, M. B., f - Element/Crown Ether Complexes. Preparation and Structural Characterization of Lanthanide Chloride Complexes of 12-crown-4. Inorg. Chem., 27, 1988, pp. 3826 - 3835.

[4] Robin, D. R., and Lynn, K. K. , f - Element/Crown Ether Complexes. Synthesis and crystal and Molecular Structures of $\left[\mathrm{MCl}\left(\mathrm{OH}_{2}\right)_{2}\left(18\right.\right.$-crown-6)]Cl $2 \cdot 2 \mathrm{H}_{2} \mathrm{O}(\mathrm{M}=\mathrm{Sm}, \mathrm{Gd}, \mathrm{Tb})$. Inorg. Chem., 26, 1987, pp. $1498-1502$.

[5] King, R. B., and Paul, R. H., Lanthanide Nitrate Complexes of Some Macrocyclic Polyethers. Journal of the American Chemical Society, 1974, 96:10.

[6] Lawrence, L. David, J. B., and Gordon, W. B., Lanthanide and Yttrium Complexes of Deprotonated 4,13-Diaza-18-crown-6 (DAC): Synthesis and Structural Characterization of $\mathrm{Y}[\mathrm{DAC}]\left[\mathrm{N}\left(\mathrm{SiMe}_{3}\right)_{2}\right]$ and the Novel Trinuclear Ytterbium(I1) Complex \{ $\mathrm{Yb}\left[\mathrm{N}\left(\mathrm{SiMe}_{3}\right)_{2} \mathrm{l}[\mu\right.$-DAC $]$ \}2Yb. Inorg. Chem., 33, 1994, pp. $5302-5308$.

[7] Sinelshchikova, A. A., Gorbunova, G. Y., Lapkina, L. A., Konstantinov, N. Y., and Tsivadze, A. Y. , Erbium Complexes with Tetra_15_crown_5_phthalocyanine: Synthesis and Spectroscopic Study. Russian Journal of Inorganic Chemistry, Vol. 56, No. 9, 2011, pp. $1370-1379$.

[8] Rita, D., Judite, C., Krassimira, P. G., and Luis, M. P. L. , Lanthanide complexes of macrocyclic derivatives useful for medical applications. Pure Appl. Chem., Vol. 77, No.3, 2005, pp. $569-579$.

[9] Taheri, K., Chamsaz, M., Rounaghi, G. H., and Ansari, M. F. , Study of complexes formation between $\mathrm{La}^{3+}, \mathrm{Ce}^{3+}$ and $\mathrm{Y}^{3+}$ cations with some 18-membered crown ethers in methanol - water and methanol - acetonitrile binary mixtures. J. Incl. Phenom. Macrocycl. Chem., 63, 2009, pp. 43 - 52.

[10] Bunzli, J. C. G. , Benefiting from the unique properties of lanthanide ions. Acc. Chem. Res. 39, 2006 , pp. 53-61.

[11] Bunzli, J. C. G., and Piguet, C. , Lanthanide-containing molecular and supramolecular polymetallic functional assemblies. Chem. Rev., 102, 2002, pp. 1897-1928.

[12] Yan-Li, Z., Lihua, L., Wenyu, Z., Chi-Hau, S., Qiaowei, L., Ognjen, S. M., Omar, M. Y., and Fraser, J. S. , Rigid-Strut-Containing Crown Ethers and [2] Catenanes for Incorporation into Metal - Organic Frameworks. Chem. Eur. J., 15, 2009 , pp. 13356 - 13380.

[13] Yakshin, V. V., Pribylova, G. A., Atamas, L. I., Vilkova, O. M., Tananaev, I. G., Tsivadze, Y., and Myasoedov, B. F. , Selective binding of ions of uranium and of transuranium and rare-earth metals with functionally substituted crown ethers. Radiochemistry 48(5), 2006, pp. 421-425.

[14] Shen, X., Zhang, J., Gao, S., Fu, S., Sun, T., Fu, J., Zhang, H., Chen, Q., and Gao, H. , Applications of Typical Supramolecular Systems in the Field of Radiochemistry. Progress in Chemistry, Vol. 23, Issue 7, 2011, pp. 1386 - 1399.

[15] Shu, K.., Shumpei, I., Tomoaki, H., and Kei, M. , The effects of substituents in catalytic asymmetric aldol reactions in aqueous media using rare earth metal salt-chiral crown ether complexes. Nippon Kagakkai Koen Yokoshu 81(2), 2002 , pp. 1243.

[16] Farnoush, F., Mohammad, R. G., Bagher, L., Parviz, N., Siavash, R., and Fatemeh, S. M. , Lanthanide Recognition: an Asymetric Erbium Microsensor Based on a Hydrazone Derivative. Sensors, 7, 2007, pp. 3119 - 3135.

[17] Maria, E. S., and Mario, S. V., Theoretical study of beryllium structures analogous to crown ethers. Computational and Theoretical Chemistry, 966, 2011, pp. $127-132$.

[18] Charles, J. P. , The Discovery of Crown Ethers. E. I. du Pont de Nemours and Company, Wilmington, Delaware, $1987,19898$.

[19] Dietrich, B., Lehn, J. M., and Sauvage, J. P. , Les Cryptates. Tetrahedron Letters, Vol. 10, Iss. 34, 1969, pp. $2889-2892$.

[20] Chang, M. C., Jiyoung, H., and Nam, J. K., Binding selectivity of dibenzo-18-crown-6 for alkali metal cations in aqueous solution: A density functional theory study using a continuum salvation model. Chemistry Central Journal, 2012, 6:84.

[21] Izatt, R. M., Bradshaw, J. S., Nielsen, S. A., Lamb, J. D., Christensen, J. J., and Sen, D. , Thermodynamic and kinetic data for cation-macrocycle interaction. Chem Rev., 85, 1985, pp. 271-339.

[22] Gokel, G. W., Leevy, W. M., and Weber, M. E. , Crown ethers: sensors for ions and molecular scaffolds for materials and biological models. Chem Rev., 104, 5, 2004, pp. 2723-2750.

[23] Gokel, G. W., Goli, D. M., Minganti, C., and Echegoyen, L. , Clarification of the hole-size cation-diameter relationship in crown ethers and a new method for determining calcium cation homogeneous equilibrium binding constants. J Am Chem Soc., 105, 1983, pp. 6786-6788.

[24] Anderson, J. D., Paulsen, E. S., and Dearden, D. V, Alkali metal binding energies of dibenzo-18-crown-6: Experimental and computational results. Int J Mass Spectrom., Vol. 227, No. 1, 2003, pp. 63-76.

[25] Alasundkar, K. N., Deshmukh, B. M., Salunkhe, D. K., and Sankpal, S. A. , Synthesis, Optical and X-ray study of transition metal complex of $\mathrm{Cu}$ (II) containing naphthaquinone dibenzo 18-crown-6. Der Chemica Sinica, 2 (2), 2011, pp. 118 - 124.

[26] Sock-Sung, Y., Sung, K. K., Hong-Ryol, S., Hyung-Sock, S., Eun, K. L., Jae-Kyung, K., and Chong-Hyeak, K. , Lanthanide Complexes of Some High Energetic Compounds (II), Crystal Structures and Thermal Properties of Picrate Complexes. Bull. Korean Chem. Soc., Vol. 26, No. 8, 2005.

[27] Lu, T., Gan, X., Tang, N., and Tan, M., Studies on Rare Earth Complexes with Crown Ethers-XIX. Synthesis and Characterization of the Complexes of Lanthanide Thiocyanates with Dibenzo-24-Crown-8. Polyhedron, Vol. 9, No. 19, 1990, pp. 2371 - 2374.

[28] Tongbu, L., Xinmin, G., and Minyu, T. , Studies on Crown Ether Complexes-XXVIII. Synthesis, Characterization and Structure of the Complexes of Heavier Lanthanide Nitrates (Gd - Lu) with Dibenzo-24-Crown-8. Polyhedron, Vol. 12, No. 13, 1993, pp. 1641 1646.

[29] Mihai, B., Claudiu, T. S., Andrea, S., Cornelia, G., Paula, D., Mihaela, B., Vlad, I., and Louis, C. , Functionalized Derivatives of Benzo-Crown Ethers. Part 4. Antifungal Macrocyclic Supramolecular Complexes of Trans m on Metal Ions Acting as Lanosterol14-o-Demethylase Inhibitors. Metal-Based Drugs, Vol. 6, No. 2, 1999.

[30] Semnani, A., Pouretedal, H. R., Nazari, B., and Firooz, A. , Spectrophotometric Study of the Compelexation of Bromine with Crown Ethers in Chloroform Solution. Scientia Iranica, Vol. 10, No. 3, 2003, pp. 317 - 321. 
[31] Azad, S., Laack, B., and Tysoe, W. T. , An investigation of the surface chemistry of crown ethers: the adsorption and reaction of 12-crown-4 on palladium (III). Surface Science, Vol. 496, 2002, pp. 87 - 96.

[32] Carnall, W. T., Gschneider, K. A. J., and Eyring, L., Handbook on the Physics and Chemistry of Rare Earths; (North-Holland Company, Amsterdam, vol. 3, 1979), pp. 171.

[33] Tongbu L., and Minyu T., Studies on Synthesis of Crown Ether Complexes-XXIX. and Characterization of the Lanthanide Isothiocyanates with 13-CROWN-4. Polyhedron, Vol. 12, No. 9, 1993, pp. 1055-1059.

[34] Cui, M. Y., Yang, H. K., Zi, R. L., Cheng, Y. W., De, H. R., Ming, A. H., and Hong, F. X., Studies on the Thermal Behavior and Decomposition Mechanism of Complexes of Rare Earth (III) Nitrates with Benzo-15-Crown-5. Journal of Thermal Analysis, Vol. 35,1989 , pp. $2471-2479$

[35] Yan, B., Zhang, H. J., Zhou, G. L., and Ni, J. Z., Different Thermal Decomposition Process of Lanthanide Complexes with NPhenylanthranilic Acid in Air and Nitrogen Atmosphere. Chem. Pap., Vol. 57, No. 2, 2003, pp. 83 - 86.

[36] Jardino, S. A. F., Isolani, P. C., and Vicentini, G., Synthesis and characterization of lanthanide picrate complexes with tripiperidinophosphine oxide. Journal of Alloys and Compounds, Vol. 249, Issues 1-2, 1997, pp. 91 - 93.

[37] Cardoso, M. C. C., Zinner, L. B., Zukerman, S. J., Araújo, M. D. M., and Vicentini, G., Complexes of lanthanide picrates with 1,4-pyrazine-dioxide. Journal of Alloys and Compounds, Vols. 323 - 324, 2001, pp. $22-25$.

[38] Nakamoto, K. , Infrared Spectra of Inorganic and Coordination Compounds ( 4th. Ed. J. Wiely and Sons, New York, 1996).

[39] Ferraro, J., Low Frequency Vibrations of Inorganic and Coordination Compounds (Ed. Plenum, New York, 1971).

[40] Green Wood, N. N. and Earnshow, A. , Chemistry of the Elements, Ed. J. Wiley and Sons Inc. New York, 18.A. B. P. Lever, Inorganic Electronic Spectroscopy, ( Ed. New York, 1968).

[41] Numan, A. Th., Alsalehe, E. I., and Aldulaimi, J. H. , Synthesis and Characterization of Tetradentate Complexes Type N2O2 From the Reaction of 2-Hydroxy -1, 2-Diphynel-Ethanone Oxime [ $\left.\mathrm{H}_{2} \mathrm{~L}\right]$ With $\mathrm{Mn}$ (II), Fe (II), Co (II), $\mathrm{Ni}$ (II), $\mathrm{Cu}$ (II) and $\mathrm{Hg}$ (II) Ions. IBN AL- HAITHAM J. FOR PURE \& APPL. SCI. Vol. 22, No. 3, 2009.

[42] Geary, W. J. , The use of conductivity measurements in organic solvents for the characterisation of coordination compounds. Coord. Chem. Rev., 7, 1971, pp. 81-122. 